\title{
INDEX OF ANTHROPOGENIC LOAD ON LAND (ALOL) AS DECISION SUPPORT METHOD IN TERRITORIAL PLANNING
}

\author{
Rimvydas GAUDE்ŠIUS (D) $1,2^{*}$ \\ ${ }^{1}$ Vytautas Magnus University, Kaunas, Lithuania \\ ${ }^{2}$ National Land Service under the Ministry of Agriculture, Vilnius, Lithuania
}

Received 08 September 2019; accepted 02 February 2020

\section{Highlights}

- The most rational usage of land in Lithuania (in case of Klaipeda city) was in 2014 and the worst situation - 2017.

- The proposed index can assess the land use situation at different time periods.

ALOL can help to select the most appropriate spatial planning document.

$\checkmark$ Comparing the proposed method with other existing methods, it can be seen that the results achieved are not worse.

The model can influence further land use by improving the economic and social situation without worsening environmental erformance.

\begin{abstract}
Not all international indexes of sustainability can be easily applied to Lithuanian specialists who organize territorial planning documents. Therefore, the index assessing the anthropogenic impact can be applied in spatial planning documents is required. The proposed method is beneficial in a way that it is based on the available free statistics data. Not only land use changes can be assessed by using presented ALOL index, but also newly presented spatial planning documents. The anthropogenic load on the land index have been calculated and the comparison with another popular multi-criteria decision support methods was conducted in this study. The results showed that the value of the anthropogenic load index is deteriorating in one of the Lithuanian metropolitan areas and the proposed method does not let others down with the precision for other mathematical methods.
\end{abstract}

Keywords: sustainable development, environmental engineering, decision support system, criteria, index.

\section{Introduction}

Sustainable development can be correctly achieved by allocating the usage of natural resources and rationally developing the infrastructure. However, if we cannot measure the current situation in the environment then we cannot control it. For that purpose appropriate indicators are needed indicating the relative position of the particular area. Environmental, social and economic indicators can form integrated indices which can guide policy decisions.

One single indicator or index for sustainable development cannot be expected as it is difficult to come up with a measure that fully embraces the concept of sustainability. R. Čiegis et al. (2010) analyzed the indicators proposed by other scientists and the requirements for them. It has been distinguished that the sustainability indicators have to be:
- Understandable, unambiguous, clear, comparable;

- Flexible for ongoing changes in society;

- Reflecting the daily quality of life;

- Allowing theories to be compared with one another;

- Conveying the development aspects of the area;

- Data has to be freely available, reliable, regularly updated;

- Be in touch with the main goals of sustainability;

- Easy to divide in time and administrative units.

Index is an aggregated measure combining individual indicators or sets of indicators. Indices are superior to indicators because dimensionless number due to indicators expressed in different units is received. Composite indexes are also valued for the possibility to integrate vast amounts of information into a format that is accessible to the public.

*Corresponding author. E-mail: rimvydas.gaudesius@vdu.lt 
As R. Čiegis et al. (2010) point out, many indicators and indices have been invented but most statistics are collected on a global scale, for example, in the European Union countries some of them are only short-term. Therefore, this makes it difficult to assess the constant changes in the relevant administrative locality. Currently, the world has officially approved and used a different number of indicators: Germany - 2018, France - 307, Denmark - 90, Portugal - 132, Finland - 88, Switzerland - 120, the US 450 and Japan -20 . Concerning the number of indicators, opinions are different because some people think that as much as possible indicators are needed and other people are of the opposite opinion that it is gaining more and more support.

Most widely used indices are criticized for the selected criteria (Table 1) because of the lack of full evaluation of sustainable development, overly complex calculations and the difficulty of finding the necessary data.

One of the most popular indexes that has received a lot of attention is the ecological footprint (EF). The Ecological Footprint is a tool of resource and emissions that measures direct and indirect human impact and the planet's skill to regenerate. The core of the ecological footprint method is the skill to express the total use of human resources per unit area of land and the global hectare (gha). This is the area of bio-productive land that is needed to produce each of the consumables and the land needed to meet the needs of one inhabitant is received when these areas of land are put together (Chominčenkaitė \& Burškytė, 2014).

Estimating the size of an ecological footprint is a complex calculation involving many sectors of activity (Juščius \& Dargienè, 2015; Staniūnas et al., 2010; Kitzes et al., 2007). Its concept has been extensively studied by many scholars interested in sustainable development but there are also many minus complexities (Kitzes et al., 2009; Vuuren \& Smeets, 2000; Gao \& Tian, 2016; Totha \& Szigeti, 2016; Marrero et al., 2017; Wackernagel et al., 2004; Gu et al., 2015).

Considering the shortcomings of existing indices, more and more new methods of estimating and calculating urban development are proposed. These new approaches are applied into the local level but they are also proposed to be used globally (Estrada \& Park, 2019; Pujiati et al., 2018). The criteria involve various aspects of coherence but it is obvious that the latter methods would still be difficult to apply for Lithuanian specialists due to

Table 1. Description of existing indices (source: prepared by the author according to Čiegis et al., 2010; Velička \& Pupalienè, 2010; Rudzkienė \& Burinskienè, 2007)

\begin{tabular}{|c|c|c|c|}
\hline Index & Measuring & Description & Negative features \\
\hline $\mathrm{EF}$ & $\begin{array}{l}\text { The size of human } \\
\text { intensively exploited area. }\end{array}$ & $\begin{array}{l}\text { The most commonly used criteria are population, land area, } \\
\text { electricity consumption, natural gas usage, gasoline usage, } \\
\text { number of transport units, types and numbers of houses, } \\
\text { recycling, and etc. }\end{array}$ & $\begin{array}{l}\text { The calculation } \\
\text { methodology is not } \\
\text { explicitly described. The } \\
\text { index mainly measures } \\
\text { ecological indicators. }\end{array}$ \\
\hline ESI & $\begin{array}{l}\text { Environmental } \\
\text { sustainability. }\end{array}$ & $\begin{array}{l}\text { The used indicators are air quality, biodiversity, soil, water } \\
\text { quality, ecosystem status, demographic situation, waste } \\
\text { recycling, healthy environment, human well-being, public sector } \\
\text { activities, science, technology, internationalization, and pollutant } \\
\text { emissions. }\end{array}$ & $\begin{array}{l}\text { There is too much focus is } \\
\text { paid on innovation in the } \\
\text { state. }\end{array}$ \\
\hline ESPI & Ecological load. & $\begin{array}{l}\text { A selection of } 6 \text { indicators for } 10 \text { strategic environmental } \\
\text { directions. }\end{array}$ & $\begin{array}{l}\text { Focusing solely on the } \\
\text { environment. }\end{array}$ \\
\hline WI & $\begin{array}{l}\text { The well-being of } \\
\text { communities. }\end{array}$ & $\begin{array}{l}\text { The index is designed to measure communities at global, } \\
\text { national or local level using } 75 \text { indicators. Indicators include soil, } \\
\text { protected areas, water quality, air quality, biodiversity, energy } \\
\text { consumption, population, education, crime, and etc. }\end{array}$ & $\begin{array}{l}\text { It is difficult to collect data } \\
\text { of indicators. }\end{array}$ \\
\hline ISEW & $\begin{array}{l}\text { Sustainable economic } \\
\text { prosperity. }\end{array}$ & $\begin{array}{l}\text { This index consists of } 21 \text { indicators ( } 14 \text { economic and } 7 \\
\text { environmental). }\end{array}$ & $\begin{array}{l}\text { The index does not measure } \\
\text { social welfare. }\end{array}$ \\
\hline HDI & $\begin{array}{l}\text { Human social } \\
\text { development. }\end{array}$ & $\begin{array}{l}\text { The average achievements of the country according to the most } \\
\text { important components of human social development: long and } \\
\text { healthy life (life expectancy), population literacy (pursuit of } \\
\text { higher education), good standard of living (GDP) are taken into } \\
\text { account. }\end{array}$ & $\begin{array}{l}\text { Environmental degradation } \\
\text { is underestimated. It is also } \\
\text { a complicated calculation. }\end{array}$ \\
\hline IPAT & $\begin{array}{l}\text { Influence of human } \\
\text { population on } \\
\text { environment. }\end{array}$ & The data used are asset level, population and technology level. & $\begin{array}{l}\text { The relationship between } \\
\text { variables is defined. If } \\
\text { three variables are constant } \\
\text { then the fourth one will be } \\
\text { constant. }\end{array}$ \\
\hline PEDA & $\begin{array}{l}\text { Negative effects of } \\
\text { development on reducing } \\
\text { agricultural output per } \\
\text { person. }\end{array}$ & $\begin{array}{l}\text { It indicates the relationship between population, development, } \\
\text { environment and agriculture. }\end{array}$ & $\begin{array}{l}\text { Quite complex } \\
\text { mathematical calculations } \\
\text { are applied. }\end{array}$ \\
\hline
\end{tabular}


the lack of data. Criteria for other new approaches only consider narrow areas, such as energy use, business impact, pavement change, and so on (Cimen, 2019; Janova et al., 2019; Rosa et al., 2019; Shah et al., 2019). There is also little assessment of sustainable development and even less of environmental engineering. However, it is noticeable that researchers from different countries offer criteria easily accessible to them.

It is very important not only to evaluate the present situation of land use but also to approve the most appropriate spatial planning document in order to develop the spatial area in the process of spatial planning. The multicriteria decision support methods widely used in other fields can be used for this purpose (Bunyan \& Yalpir, 2019; Cai et al., 2019; Oudenhoven et al., 2019; Guarini \& Battisti, 2016; Rose et al., 2016; Hallstedt, 2015; Mosadeghi et al., 2015; Zhang et al., 2012). Major scientific researches on the use of these methods in spatial planning have already been conducted on (Mulliner et al., 2016; Giudice et al., 2019; Tang et al., 2019).

Multiple criteria decision support methods are also being developed (WSM, WPM, TOPSIS, MAUT, AHP, FUZZY, SAW, etc.). It is stated that there is no universal method appropriate to evaluate all multi-criteria decision analysis problems as each method has its own advantages and disadvantages.

Comparing labor costs, it is being assessed whether a particular method requires specific software helping to evaluate the results of the task and how much effort is required to calculate them. No special software is required for application of WSM and WPM methods, even for a relatively large-scale task. In contrast, applying priority methods of TOPSIS or MAUT methods even for small scale multicriteria tasks it is difficult to calculate without special software. In the case of AHP and FUZZY methods, application of special software depends on the complexity of the task (Poškas et al., 2012).

Most of these methods do not do without an expert evaluation of the criteria which sometimes becomes complicated and biased. The right selection of criteria has a great influence on this process (Said et al., 2016; Roshanfekr et al., 2016).

Considering the methods listed in the literature, in order to compare the proposed method with another known and widely used methods (TOPSIS and SAW), the comparison is made at the end of the study. These methods have been selected because they are different in calculation and can be used without the expert assessment (criteria weights).

The TOPSIS method was introduced by Kwangsun Yoon and Hwang Ching-Lai in 1981. The main idea is an alternative which is at the shortest distance to the ideal selection and the longest distance to the poorest one. This method is highly universal due to its capacity in usage of different type's data. Therefore, it is applicable in various fields, such as mechanical engineering, medicine, computer science, management, etc. (Markovic, 2010; Saraff et al., 2013; Ahmadi et al., 2013; Soufi et al., 2015; Karim \& Karmaker, 2016; Przemyslaw et al., 2019; Oktaviana et al., 2019; Kacprzak, 2019; Jiang et al., 2019).

The SAW method is one of the longest used ones. It is calculated in the simplest way. Thus, it is one of the most popular multi-criteria solution supporting methods. Weighted averages are used in calculations as a respective value is given to each alternative. Since this method is one of the oldest ones, many modifications have been proposed aiming at correction of the shortcomings discovered. The SAW modifications were used in this calculation (Memariani et al., 2009; Afshari et al., 2010; Podvezko, 2011; Salehi \& Izadikhah, 2014; Karlitasari et al., 2017; Abadi et al., 2019).

As it was mentioned, another indices consider only narrow areas (Cimen, 2019; Janova et al., 2019; Rosa et al., 2019; Shah et al., 2019) and they do not highlight anthropogenic load on land. The multi-criteria decision support methods are very popular and widely used in new researches (Bunyan \& Yalpir, 2019; Cai et al., 2019; Oudenhoven et al., 2019). These methods become more and more influential in spatial planning (Giudice et al., 2019; Tang et al., 2019), so ALOL index will supplement this field. The presented index will fill the gap of sustainability indices because offered criteria will be easy applied for Lithuanian specialists. All these facts shows novelty of this job.

The object of this research is to propose the new index that would measure anthropogenic load on the earth, to calculate its values in one of the cities of Lithuania and to compare its possibilities as multi-criteria method of decision support comparing with another mathematical method used for a long time. The research is significant and important because the newly proposed index will be used in assessing of land use in different periods and as the tool of evaluating different concepts of the master plan using the selected criteria.

\section{Material and methods}

One of the largest cities in Lithuania, Klaipeda, was selected for the research. This administrative area is quite heavily influenced by the anthropogenic processes, so it is appropriate to carry out measurements using the newly developed ALOL index achieving to find out the numerical value of land use changes.

Calculations were performed using Excel program. The widely used TOPSIS and SAW methods were selected for comparison of the concepts of spatial planning documents. Data of the period from 2012 to 2017 of Statistics Department, National Land Service, State Enterprise Center of Registers and State Land Fund was used.

SAW and TOPSIS methods have been selected for their reliability and long-term usage in another studies. These methods are actively used in current research as it is apparent from the latest scientific publications. These methods have been selected regarding the simpler calculation 
methodology helping to collect and describe data of considerable amount of land plots and much time spent for the research. It is also possible to determine the weights of the set criteria instead of an expert survey.

As it is seen from the literature review, indices are used in scientific practice in order to measure the sustainability of land development consists of criteria that is not directly related to land use. The index proposed in this study (anthropogenic land-load index (ALOL)) aims at focusing more directly on land use and anthropogenic impacts.

Not only buildings have a negative impact on the natural environment (soil sealing, landscaping, pollution), they also create a good effect that meets socio-economic human needs. In order to meet these needs, there have to be sufficient diversity of structures and deployment in the area concerned. The number of buildings depends on the number of inhabitants and legal entities as this corresponds to the real need. Neither in scientific literature nor in practice it is clear how many and what structures are sufficient. It is also unclear in what relationship the distribution of land may be considered rational. Therefore, it is only possible to estimate what structures or usages should increase or decrease.

All the collected indicators are of different dimensions and different significance for spatial planning. Considering these characteristics, it is appropriate to normalize these ratios and in regard with the use of centric data it is appropriate to aggregate them to monitor the change over time. In order to see a more detailed situation consisting of three directions of coherence the method also presents the individual components of the index (Formula (1)).

$$
A L O L=N_{a}+N_{s}+N_{e},
$$

where: $N_{a}$ - the sum of the values of the normalized environmental criteria; $N_{s}$ - sum of values of normalized social criteria; $N_{e}$ - sum of values of normalized economic criteria.

The normalization of the indicators and the determination of values are carried out according to the formulas (Formula (2)-(3)

$$
N_{x}=\frac{a_{i i}}{\sqrt{\sum a_{i i}^{2}}}
$$

where: $a_{i i}$ - the value of the relevant criterion indicator after the change:

$$
a_{i i}=a_{i-1}-a_{i},
$$

where: $a_{i}$ - the value of the relevant criterion indicator.

The ALOL index uses thirty five criteria, which are divided into three groups: environmental, social, economic (Table 2).

The criteria listed have been selected with respect to other indices used internationally: free access to data in Lithuania; what forms the positive or negative impact on the environment, social, economic well-being; how rational land use is perceived and what causes the effect of sealing the earth.
The ALOL measurement index after normalization is calculated in dimensionless, centric units. Relative units take on a positive or negative value depending on the achievement of the relevant criterion.

The practical application of the proposed ALOL method in the territorial planning process can be illustrated schematically (Figure 1). In particular, the collection of the necessary statistics shall take into account the current land use situation. Several document concepts are developed and indexed. The most appropriate concept can be selected under the best value or data can be edited by modifying the planning document solutions. Document solutions are changed and evaluated until the index value meets needs and such document is validated.

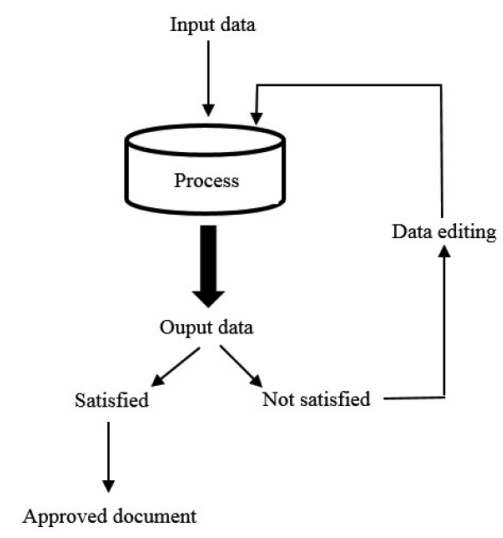

Figure 1. ALOL model algorithm

The second part of the study, using the same criteria values, aims at evaluating of spatial planning concepts. Four concepts of master plans are selected which indicate the values of the planned (predicted) criteria.

Calculations using TOPSIS method are used to set up indicators in a matrix (Formula (4)), values are normalized (Formula (5)), distances to the worst and best selection are calculated and ranking is performed (Formulas (6)-(8)):

$$
\begin{aligned}
& D M=\left[\begin{array}{ccc}
X_{11} & \cdots & X_{1 m} \\
\vdots & \ddots & \vdots \\
X_{n 1} & \cdots & X_{n m}
\end{array}\right] ; \\
& N_{n_{w} m_{w}}=\frac{X_{n_{w} m_{w}}}{\sqrt{\sum X_{n_{w} m_{w}}^{2}}} ; \\
& S_{i}^{+}=\sqrt{\sum\left(N_{n_{w} m_{w}}-\max N_{n_{w}}\right)^{2}} ; \\
& S_{i}^{-}=\sqrt{\sum\left(N_{n_{w} m_{w}}-\min N_{n_{w}}\right)^{2}} ; \\
& D S_{n}=\frac{S_{i}^{-}}{\left(S_{i}^{+}+S_{i}^{-}\right)} .
\end{aligned}
$$


The previously formed value matrix is normalized by the Formulas no. 9-10 and the ranking is performed by the Formula no. 11 in the SAW method:

$$
\begin{aligned}
& N_{n m}^{+}=\frac{X_{n m}}{\max X_{n}} ; \\
& N_{n m}^{-}=\frac{\min X_{n}}{X_{n m}} ; \\
& D S_{n}=\sum W_{i} N_{n m} .
\end{aligned}
$$

All three methods propose the best alternative with the highest numerical value. After the calculations have been made the result table is created (Table 3 ).

\section{Results}

Calculation of the ALOL index in the case of Klaipeda showed that the numerical value of the anthropogenic load on the land, although positive, shows a decrease in the result over several years (Figure 2). This is mainly due

\begin{tabular}{|c|c|c|c|c|c|}
\hline \multicolumn{2}{|c|}{ Environmental } & \multicolumn{2}{|c|}{ Social } & \multicolumn{2}{|c|}{ Economic } \\
\hline Criteria $(A x)$ & Goals & Criteria & Goals & Criteria & Goals \\
\hline $\begin{array}{l}\text { Discharged wastewater } \\
\text { (without treatment) to } \\
\text { surface waters (A1). }\end{array}$ & $\begin{array}{l}\text { To reduce the amount of } \\
\text { waste and environmental } \\
\text { pollution. }\end{array}$ & \multirow[t]{2}{*}{$\begin{array}{l}\text { Number of } \\
\text { administrative } \\
\text { buildings. }\end{array}$} & \multirow[t]{2}{*}{$\begin{array}{l}\text { To ensure service } \\
\text { delivery and } \\
\text { diversity. }\end{array}$} & \multirow{4}{*}{$\begin{array}{l}\text { Industrial, } \\
\text { production, } \\
\text { storage, } \\
\text { garage } \\
\text { structures. }\end{array}$} & \multirow{4}{*}{$\begin{array}{l}\text { Economic } \\
\text { growth, } \\
\text { ensuring } \\
\text { diversity of } \\
\text { services. }\end{array}$} \\
\hline Air pollution by sulfur & Reduction of air pollution. & & & & \\
\hline dioxide (A2). & & \multirow{5}{*}{$\begin{array}{l}\text { Number of cultural } \\
\text { centers and } \\
\text { museums in the } \\
\text { territory. }\end{array}$} & \multirow{5}{*}{$\begin{array}{l}\text { Access to full- } \\
\text { fledged services } \\
\text { and social welfare. }\end{array}$} & & \\
\hline Air pollution with nitric & Reduction of air pollution. & & & & \\
\hline & & & & Number of & Economic \\
\hline $\begin{array}{l}\text { Air pollution by carbon } \\
\text { monoxide (A4). }\end{array}$ & Reduction of air pollution. & & & $\begin{array}{l}\text { transport } \\
\text { objects } \\
\text { (stations, }\end{array}$ & growth \\
\hline \multirow{2}{*}{$\begin{array}{l}\text { Air pollution by volatile } \\
\text { organic compounds (A5). }\end{array}$} & \multirow[t]{2}{*}{ Reduction of air pollution. } & & & ports, etc.). & \\
\hline & & \multirow{2}{*}{$\begin{array}{l}\text { Number of special } \\
\text { purpose buildings } \\
\text { (fire, police, } \\
\text { barracks, etc.). } \\
\end{array}$} & \multirow{2}{*}{$\begin{array}{l}\text { To ensure diver- } \\
\text { sity of services, } \\
\text { social welfare and } \\
\text { security. }\end{array}$} & & \\
\hline $\begin{array}{l}\text { Air pollution by fluorine and } \\
\text { other pollutants (A6). }\end{array}$ & Reduction of air pollution. & & & & \\
\hline \multirow{2}{*}{\begin{tabular}{|l|}
$\begin{array}{l}\text { Air pollution by hard } \\
\text { particles (A7). }\end{array}$ \\
\end{tabular}} & Reduction of air pollution. & \multirow{3}{*}{$\begin{array}{l}\text { Number of health } \\
\text { care buildings. }\end{array}$} & \multirow{3}{*}{$\begin{array}{l}\text { To ensure health } \\
\text { care. }\end{array}$} & \multirow{5}{*}{$\begin{array}{l}\text { Number of } \\
\text { agricultural } \\
\text { structures. }\end{array}$} & \multirow{5}{*}{$\begin{array}{l}\text { Economic } \\
\text { growth. }\end{array}$} \\
\hline & Preservation of biodiversity. & & & & \\
\hline Gardens area in the territory & Preservation of biodiversity. & & & & \\
\hline (A9). & & \multirow{4}{*}{$\begin{array}{l}\text { Number of religious } \\
\text { buildings. }\end{array}$} & \multirow{4}{*}{$\begin{array}{l}\text { To ensure social, } \\
\text { leisure and } \\
\text { cultural well- } \\
\text { being. }\end{array}$} & & \\
\hline \multirow{2}{*}{$\begin{array}{l}\text { Area of grassland and } \\
\text { natural pastures (A10). }\end{array}$} & \multirow[t]{2}{*}{ Preservation of biodiversity. } & & & & \\
\hline & & & & \multirow{4}{*}{$\begin{array}{l}\text { Number of } \\
\text { caterers. }\end{array}$} & \multirow{4}{*}{$\begin{array}{l}\text { Increasing } \\
\text { employ- } \\
\text { ment, } \\
\text { access to } \\
\text { services } \\
\text { and } \\
\text { economic } \\
\text { growth. }\end{array}$} \\
\hline $\begin{array}{l}\text { Forest are in the territory } \\
\text { (A11). }\end{array}$ & Preservation of biodiversity. & & & & \\
\hline Total road area (A12). & $\begin{array}{l}\text { Reduction of soil } \\
\text { destruction. }\end{array}$ & \multirow[t]{3}{*}{$\begin{array}{l}\text { Number of sport } \\
\text { facilities. }\end{array}$} & \multirow[t]{3}{*}{$\begin{array}{l}\text { To ensure better } \\
\text { health. }\end{array}$} & & \\
\hline Space of built-up area (A13). & $\begin{array}{l}\text { Reduction of soil } \\
\text { destruction. }\end{array}$ & & & & \\
\hline Water area (A14). & To preserve water areas. & & & \multirow{4}{*}{$\begin{array}{l}\text { Number of } \\
\text { accommo- } \\
\text { dation } \\
\text { establish- } \\
\text { ments, } \\
\text { hotels and } \\
\text { recreational } \\
\text { facilities. }\end{array}$} & \multirow{4}{*}{$\begin{array}{l}\text { Economic } \\
\text { growth, } \\
\text { promotion } \\
\text { of tourism. }\end{array}$} \\
\hline Trees and shrubs area (A15). & Preservation of biodiversity. & $\begin{array}{l}\text { Number of educa- } \\
\text { tional establishments } \\
\text { in the territory. }\end{array}$ & $\begin{array}{l}\text { Opportunity for } \\
\text { lifelong learning. }\end{array}$ & & \\
\hline Wetland area (A16). & Preservation of biodiversity. & \multirow{3}{*}{$\begin{array}{l}\text { Number of } \\
\text { residential houses in } \\
\text { the territory. }\end{array}$} & \multirow{3}{*}{$\begin{array}{l}\text { To ensure } \\
\text { affordable } \\
\text { accommodation } \\
\text { for all residents. }\end{array}$} & & \\
\hline Damaged area (A17). & Biodiversity loss. & & & & \\
\hline $\begin{array}{l}\text { Brownfield (unused) area } \\
\text { (A18). }\end{array}$ & Reduction of brownfields. & & & \multirow{3}{*}{$\begin{array}{l}\text { Number } \\
\text { of trade } \\
\text { and service } \\
\text { buildings. }\end{array}$} & \multirow{3}{*}{$\begin{array}{l}\text { Increasing } \\
\text { of employ- } \\
\text { ment, } \\
\text { access to } \\
\text { services } \\
\text { and eco- } \\
\text { nomic } \\
\text { growth. }\end{array}$} \\
\hline Drained area (A19). & Preservation of biodiversity. & $\begin{array}{l}\text { Lenght of bicycle } \\
\text { lanes. }\end{array}$ & $\begin{array}{l}\text { Promotion of } \\
\text { green mobility } \\
\text { and healthy living. }\end{array}$ & & \\
\hline $\begin{array}{l}\text { Area of conservative } \\
\text { purposes (A20). }\end{array}$ & $\begin{array}{l}\text { Reduction of soil } \\
\text { destruction. }\end{array}$ & & & & \\
\hline
\end{tabular}
to the deterioration of the environmental criteria $(\mathrm{Na})$.

Table 2. ALOL Index Criteria (source: prepared by the author) 
All criteria were positive in 2013 and 2014. Social (Ns) and economic $(\mathrm{Ne})$ indicators remain similar throughout the study period. Comparing how the situation of 2017 changed from 2014 (best ALOL value) it was found that the values of environmental indicators decreased by 1.889 units, social values increased by 0.004 units and economic values decreased by 0.200 units. The ALOL index decreases by 2.049 units during the period. Although ALOL value is not negative, however, it is decreasing and this change is significant.

The calculations were made using the described methodology (Formulas (1)-(3)) and statistical data of land usage. All the criteria are compared with each other over a period of time, results shows changes in land usage and a mathematical representation of the real situation. There is the detailed part of the calculations in the table (Table 3).
During the study period, the change of Na value ranges from 0.5246 to 1.8413 unit. The change of ALOL value ranges from 0.2927 to 1.6206 . Considering the tendency of situation deterioration, it can be assumed that the $\mathrm{Na}$ value may decline averagely by 1.1829 units each year and ALOL values by 0.9566 units.

ALOL values can be positive (land use is improving) or negative (land use is deteriorating) with estimates of up to 1 land use change of little significance and above 1 that is obviously significant. However, it is sensible to explore these meanings and their limits in more detailed way in future work.

The further goal of the work is to test the proposed ALOL index as a multi-criteria method of decision support and to compare it with another popular method. The comparison examines the distribution of alternatives and

Table 3. Calculation of Na. The results show Na value for 2017

\begin{tabular}{|c|c|c|c|c|c|c|c|}
\hline $\begin{array}{c}\text { Environmental } \\
\text { Criteria (Ax) }\end{array}$ & $\begin{array}{c}\text { Data of } \\
2016\end{array}$ & $\begin{array}{c}\text { Data of } \\
2017\end{array}$ & Ambition & Relative size & Relative size & Ambition value & Normalization \\
\hline $\mathrm{A} 1$ & 19.1 & 17.2 & Min & 0.017764302 & 0.016022954 & 0.0017413483 & 0.0000467489 \\
\hline A2 & 1125 & 964 & Min & 11.46246831 & 9.841595237 & 1.6208730758 & 0.0435145425 \\
\hline $\mathrm{A} 3$ & 6462 & 7459 & Min & 65.84041799 & 76.1498536 & -10.3094356133 & -0.2767708226 \\
\hline A4 & 14867 & 18312 & Min & 151.4777924 & 186.949473 & -35.4716806459 & -0.9522855179 \\
\hline A5 & 4833 & 4453 & Min & 49.24276387 & 45.46122779 & 3.7815360811 & 0.1015204800 \\
\hline A6 & 1301 & 1248 & Min & 13.2557078 & 12.74098636 & 0.5147214351 & 0.0138183971 \\
\hline A7 & 1628 & 1860 & Min & 16.58746526 & 18.98897006 & -2.4015048068 & -0.0644716632 \\
\hline A8 & 559.42 & 559.43 & Min & 0.056998525 & 0.057112901 & -0.0001143760 & -0.0000030706 \\
\hline A9 & 38.46 & 38.46 & Max & 0.003918636 & 0.003926429 & 0.0000077931 & 0.0000002092 \\
\hline A10 & 1201.67 & 1195.81 & Max & 0.122436483 & 0.122081722 & -0.0003547606 & -0.0000095240 \\
\hline A11 & 2032 & 2031.89 & Max & 0.20703765 & 0.207438163 & 0.0004005135 & 0.0000107523 \\
\hline $\mathrm{A} 12$ & 503.46 & 504.54 & Min & 0.051296838 & 0.051509113 & -0.0002122745 & -0.0000056988 \\
\hline $\mathrm{A} 13$ & 3329.09 & 3334.97 & Min & 0.339196343 & 0.340471212 & -0.0012748689 & -0.0000342256 \\
\hline $\mathrm{A} 14$ & 1075.19 & 1073.46 & Max & 0.109549612 & 0.109590859 & 0.0000412476 & 0.0000011073 \\
\hline A15 & 644.93 & 644.74 & Max & 0.065711019 & 0.065822304 & 0.0001112846 & 0.0000029876 \\
\hline A16 & 9.23 & 9.23 & Max & 0.000940432 & 0.000942302 & 0.0000018703 & 0.0000000502 \\
\hline A17 & 0 & 1.14 & Min & 0 & 0.000116384 & -0.0001163840 & -0.0000031245 \\
\hline A18 & 537.2 & 553.59 & Min & 0.05473456 & 0.056516688 & -0.0017821280 & -0.0000478437 \\
\hline A19 & 1547.56 & 941.47 & Min & 0.157678733 & 0.096115837 & 0.0615628962 & 0.0016527397 \\
\hline A20 & 19.4932 & 20.5861 & Max & 0.001986135 & 0.00210166 & 0.0001155254 & 0.0000031014 \\
\hline $\mathrm{Na}$ & & & & & & & -1.133059682 \\
\hline
\end{tabular}

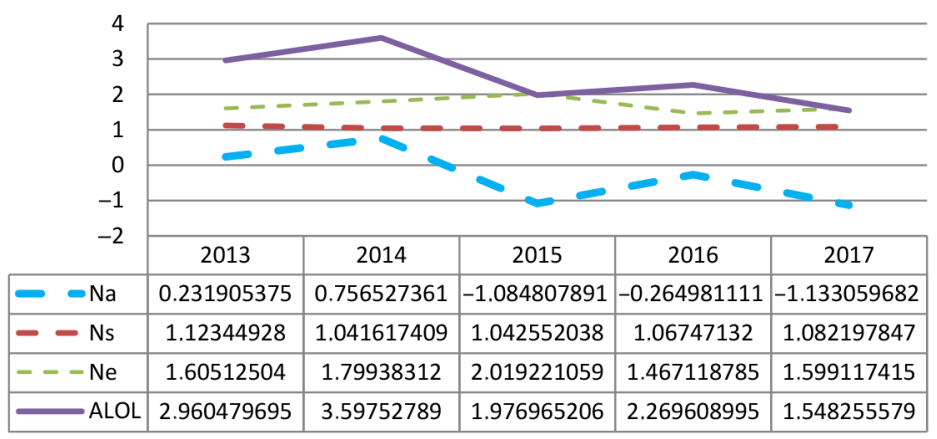

Figure 2. ALOL results in case of Klaipeda city. The data showed deteriorating land usage 
Table 4. Ranking of alternatives. The results show which documents are suitable by different methods

\begin{tabular}{|c|c|c|c|c|c|c|c|c|c|c|c|}
\hline Method & $\begin{array}{c}\text { 1st place, } \\
\text { number } \\
\text { of alter- } \\
\text { native }\end{array}$ & $\begin{array}{l}\text { Value of } \\
\text { calcu- } \\
\text { lations }\end{array}$ & $\begin{array}{l}\text { Diffe- } \\
\text { rence } \\
\text { between } \\
\text { places } 1 \\
\text { and } 2\end{array}$ & $\begin{array}{c}\text { 2nd } \\
\text { place, } \\
\text { number } \\
\text { of alter- } \\
\text { natives }\end{array}$ & $\begin{array}{l}\text { Meaning } \\
\text { of } \\
\text { calcula- } \\
\text { tions }\end{array}$ & $\begin{array}{l}\text { Diffe- } \\
\text { rence } \\
\text { between } \\
\text { 2nd } \\
\text { and 3rd } \\
\text { places }\end{array}$ & $\begin{array}{c}\text { 3rd } \\
\text { place, } \\
\text { number } \\
\text { of alter- } \\
\text { native }\end{array}$ & $\begin{array}{l}\text { Meaning } \\
\text { of } \\
\text { calcula- } \\
\text { tions }\end{array}$ & $\begin{array}{c}\text { Diffe- } \\
\text { rences } \\
\text { between } \\
3 \text { rd } \\
\text { and 4th } \\
\text { places }\end{array}$ & $\begin{array}{l}\text { 4th place, } \\
\text { number } \\
\text { of } \\
\text { alterna- } \\
\text { tives }\end{array}$ & $\begin{array}{c}\text { Meaning } \\
\text { of calcu- } \\
\text { lations }\end{array}$ \\
\hline SAW & 2 & 0.3456 & 0.0002 & 4 & 0.3454 & 0.0005 & 3 & 0.3449 & 0.0017 & 1 & 0.3432 \\
\hline TOPSIS & 1 & 0.5821 & 0.1071 & 4 & 0.4750 & 0.0307 & 3 & 0.4443 & 0.0752 & 2 & 0.3691 \\
\hline ALOL & 4 & -1.6350 & 0.0058 & 3 & -1.6408 & 0.0136 & 1 & -1.6544 & 0.0294 & 2 & -1.6838 \\
\hline
\end{tabular}

the numerical difference between the rankings of alternatives (Table 4). Four simulation documents of different territorial planning (concepts of Klaipeda city master plan solutions) have been selected for the research.

As the results show, all comparative methods offer different alternatives in the first selection (SAW - alternative 2 ; TOPSIS - 1 ; ALOL - 4). The numerical differences between the alternatives indicate that the preferred alternative proposed by the TOPSIS method is the most guaranteed (0.1071) and the last one is the one proposed by the SAW method (0.0017). It is emphasized that these two alternatives are the first and last suggestion of the different methods. The ALOL method puts the alternatives with less significant differences $(0.0058-0.0294)$, so it is likely that the method is sensitive enough to change the criteria indicators.

It can be observed that the priority alternative proposed by the ALOL method is the second-ranked alternative proposed by other method. In addition, the last ALOL alternative coincides with the last alternative of TOPSIS. These results demonstrate that the ALOL method is no worse than the well-known and widely used methods for many years.

As it is indicated in the methodology, the concepts developed in the territorial planning document can be edited as needed by changing the relevant criteria data. After the data has been edited, the index is recalculated and the positive value of the index can validate the prepared document (Figure 3). The example shows changing the socio-economic criteria data giving a positive index value.

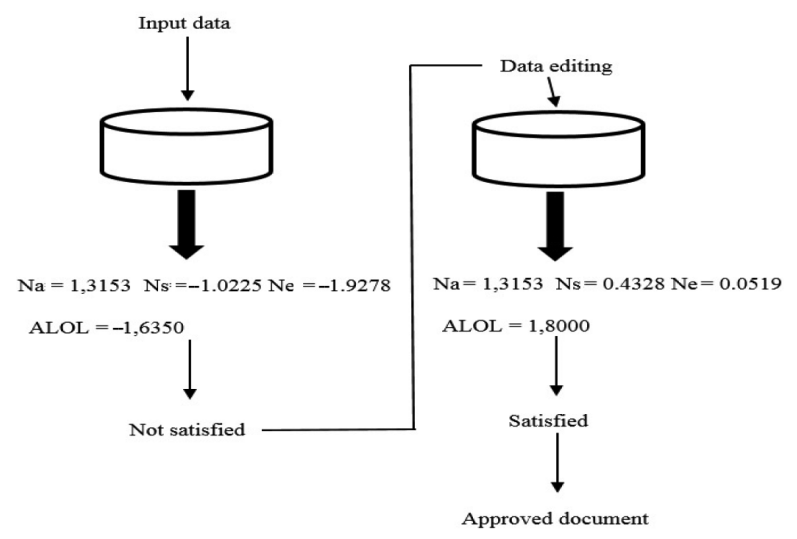

Figure 3. ALOL model operation example
Considering that this work introduces the ALOL method for the first time, future research will seek to determine the sensitivity of criteria to one another, the set of index values, the determination of criteria weights by experts and measuring values of other cities.

\section{Conclusions}

Urbanization in the world takes place on the basis of spatial planning documents drawn up on different principles. This process is shaped by political decisions and philosophical ideas. There are more liberal processes in one place and conservative elsewhere. In view of the deterioration of the environment, stricter control of spatial planning by engineering methods is proposed. The ALOL index is proposed to be used in this procedure.

The ALOL index uses 35 criteria which are divided into 3 groups. It meets all the requirements of the literature for indexes. Data is easy accessible and calculations are simple. The higher value of the ALOL index is the better coherence of the studied area is.

ALOL values of 5 year period from 2013 to 2017 were calculated in this study. According to the calculations performed, the most rational use of land in Klaipeda city was in 2014 (3.5975) and the worst situation was in 2017 (1.5482). Comparing to other years, there is also a positive change between the years but analysis of the results of several years shows a weakening of the change and a decrease in the numerical value of the ALOL index. Analysis of the individual components of the index reveals that groups of socio-economic indicators consistently show positive and significant change. The group of environmental indicators has been deteriorating in recent years. While comparing the situation change within the period from 2014 to 2017 it was found that the values of environmental indicators decreased by 1.889 units, social values increased by 0.004 units and economic values decreased by 0.200 units. The ALOL index decreases by 2.049 units during the period.

The proposed land use index (method) can not only assess the land use situation at different time periods, but it can also help to select the most appropriate spatial planning document prepared in accordance with the principles of sustainable development. Comparing the proposed method with other existing methods it can be observed that the results achieved are not worse or even more accurate. The numerical differences between the alternatives 
indicate that the preferred alternative proposed by the TOPSIS method is the most guaranteed (0.1071) and the last one is the one proposed by the SAW method (0.0017). The ALOL method puts the alternatives with less significant differences $(0.0058-0.0294)$, so it is likely that the method is sensitive enough to changed value of the criteria. The process of data normalization and ranking of results differs from the comparison methods. The model can influence further land use by improving the economic and social situation in the selected administrative area without worsening environmental performance.

\section{References}

Abadi, S., Walidi, J., Hawi, A., Akla, Dacholfany, I., Huda, M., Shukri Mat Teh, K., Hashim, W., \& Maseleno, A. (2019). Identification of sundep, leafhopper and fungus of paddy by using fuzzy SAW method. Journal of International Pharmaceutical Research, 11(1), 695-699.

https://doi.org/10.31838/ijpr/2019.11.01.093

Afshari, A., Mojahed, M., \& Yusuff, R. M. (2010). Simple additive weighting approach to personnel selection problem. International Journal of Innovation, Management and Technology, 1(5), 511-515.

Ahmadi, H., Rad, M. S., Nilashi, M., Ibrahim, O., \& Almaee, A. (2013). Ranking the micro level critical factors of electronic medical records adoption using TOPSIS method. Health Informatics - An International Journal, 2(4), 19-32.

https://doi.org/10.5121/hiij.2013.2402

Bunyan, U. F., \& Yalpir, S. (2019). Valuations of builindg plots using the AHP method. International Journal of Strategic Property Management, 23(3), 197-212.

https://doi.org/10.3846/ijspm.2019.7952

Cai, X., Jiang, Z., Liu, Q., \& Shi, H. (2019). Research on frequency hopping synchronization strategies based on TOPSIS method. Journal of Physics, 1187(5).

https://doi.org/10.1088/1742-6596/1187/5/052034

Chominčenkaitè, L., \& Burškyte, V. (2014). Assessing the ecological footprint of a seaside school community. Retrieved May 21, 2016, from http://journals.ku.lt/index.php/TMD/article/ download/234/191

Cimen, A. (2019). The impact of sustainability index on firm performance: An event study. International Journal of Contemporary Economics and Administrative Sciences, 9, 94-118.

Čiegis, R., Tamošiūnas, T., Ramanauskienè, J., \& Navickas, K. (2010). Assessment of sustainable industrial zones (pp. 70164). Siauliai University, Vilnius University.

Estrada, M., \& Park, D. (2019). The application of the Gross City Development Index (GCD-Index) in Tokyo, Japan. Economic Analysis and Policy, 62, 37-46.

https://doi.org/10.1016/j.eap.2018.12.002

Gao, J., \& Tian, M. (2016). Analysis of over-consumption of natural resources and the ecologicaltrade deficit in China based on ecological footprints. Ecological Indicators, 61, 899-904. https://doi.org/10.1016/j.ecolind.2015.10.044

Del Giudice, V., De Paola, P., Francesca, T., Nijkamp, P. J., \& Shapira, A. (2019). Real estate investment choices and decision support systems. Sustainability, 11, 3110.

https://doi.org/10.3390/su11113110

Gu, Q., Wang, H., Zheng, Y., Zhu, J., \& Li, X. (2015). Ecological foot print analysis for urban agglomeration sustainability in the middle stream of the Yangtze River. Ecological Modelling, 318, 86-99. https://doi.org/10.1016/j.ecolmodel.2015.07.022
Guarini, M. R., \& Battisti, F. (2016). Application of a multi-criteria and participated evaluation procedure to select typology of intervention to redevelop degraded urban area. Social and Bechavioral Sciences, 223, 960-967.

https://doi.org/10.1016/j.sbspro.2016.05.329

Hallstedt, S. I. (2015). Sustainability criteria and sustainability compliance index for decision support in product development. Journal of Cleaner Production, 30, 1-16. https://doi.org/10.1016/j.jclepro.2015.06.068

Janova, J., Hampel, D., \& Nerudová, D. (2019). Design and validation of a tax sustainability index. European Journal of Operational Research, 298, 916-926. https://doi.org/10.1016/j.ejor.2019.05.003

Jiang, W., Wang, M., Deng, X., \& Gou, L. (2019). Fault diagnosis based on TOPSIS method with Manhattan distance. Advances in Mechanical Engineering, 11(3), 1-12. https://doi.org/10.1177/1687814019833279

Juščius, V., \& Dargienè, D. (2015). Socially responsible consumption in Lithuania: Consumer characteristics. Bridges, 2, 47-65.

Kacprzak, D. (2019). Fyzzy TOPSIS method for group decision making. Multiple Criteria Decision Making, 13, 117-132. https://doi.org/10.22367/mcdm.2018.13.07

Karim, R., \& Karmaker, C. L. (2016). Machine selection by AHP and TOPSIS methods. American Journal of Industrial Engineering, 4(1), 7-13.

Karlitasari, L., Suhartini, D., \& Benny. (2017). Comparison of simple additive weighting (SAW) and composite performance index (CPI) methods in employee remuneration determination. In IOP Conference Series: Materials Science and Engineering, 166, 012020.

https://doi.org/10.1088/1757-899X/166/1/012020

Kitzes, J., Galli, A., Bagliani, M., Barrett, J., Dige, G., Ede, S., Erb, K., Giljum, S., Haberl, H., Hails, C., Jolia-Ferrier, L., Jungwirth, S., Lenzen, M., Lewis, K., Loh, J., Marchettini, N., Messinger, H., Milne, K. et al. (2009). A research agenda for improving national Ecological Footprint accounts. Ecological Economics, 68(7), 1991-2007.

https://doi.org/10.1016/j.ecolecon.2008.06.022

Kitzes, J., Peller, A., Goldfinger, S., \& Wackernagel, M. (2007). Current methods for calculating national ecological footprint accounts. Science for Environment and Sustainable Society, 4(1), 1-9.

Markovic, Z. (2010). Modification of TOPSIS method for solving of multicriteria tasks. Yugoslav Journal of Operations Research, 20(1), 117-143. https://doi.org/10.2298/YJOR1001117M

Marrero, M., Puerto, M., Rivero-Camacho, C., Freire-Guerrero, A., \& Solís-Guzmán, J. (2017). Assessing the economic impact and ecological footprint of construction and demolition waste during the urbanization of rural land. Resources, Conservation and Recycling, 117, 160-174. https://doi.org/10.1016/j.resconrec.2016.10.020

Memariani, A., Amini, A., \& Alireza, A. (2008). Sensitivity analysis of Simple Additive Weighting method (SAW): The results of change in the weight of one attribute on the final ranking of alternatives. Journal of Optimization in Industrial Engineering, 2(4), 13-18.

Mosadeghi, R., Warnken, J., Tomlinson, R., \& Mirfenderesk, H. (2015).Comparision of Fuzzy-AHP and AHP in a spatial multi-criteria decision making model for urban land-use planning. Computers, Environmental and Urban Systems, 49, 54-65. https://doi.org/10.1016/j.compenvurbsys.2014.10.001

Mulliner, E., Malys, N., \& Maliene, V. (2016). Comparative analysis of MCDM methods for the assessment of sustainable housing affordability. Omega, 59, 146-156. https://doi.org/10.1016/j.omega.2015.05.013 
Oktaviana, S., Rozzaaq, A., \& Rosatama, D. A. (2019). Comparative analysis using WP and TOPSIS method to find the best mountain for hiking. Journal of Physics, 1193, 012023. https://doi.org/10.1088/1742-6596/1193/1/012023

Oudenhoven, A. P. E. van, Aukes, E., Bontje, L. E., Vikolainen, V., van Bodegom, P. M., \& Slinger, J. H. (2019). Mind the Gap between ecosystem services classification and strategic decision making. Ecosystem Services, 33, 77-88. https://doi.org/10.1016/j.ecoser.2018.09.003

Podvezko, V. (2011). The comparative analysis of MCDA methods SAW and COPRAS. Engineering Economics, 22(2), 134-146. https://doi.org/10.5755/j01.ee.22.2.310

Poškas, G., Poškas, P., Sirvydas, A., \& Šimonis, A. (2012). Application of multi-critical analysis method in selection of Ignalina AEV1 building equipment disassembly method. Energetics, 58(2), 86-96.

Przemyslaw, L., Wojcik, L. J., \& Strek, Z. (2019). Application of TOPSIS method to hierarchization of land consolidation works. World Multidisciplinary Earth Sciences Symposium, 221, 012068. https://doi.org/10.1088/1755-1315/221/1/012068

Pujiati, A., Bowo, P., \& Nihayah, D. (2018). The urban sustainability index in urban aglomeration. Journal of Economics and Policy, 11(2), 294-305.

https://doi.org/10.15294/jejak.v11i2.16052

Rosa, F. S., Lunkes, R. J., \& Brizzolla, M. M. B. (2019). Data on the environmental sustainability index of large Brazilian companies. Data in Brief, 24, 103819. https://doi.org/10.1016/j.jclepro.2018.12.042

Rose, D. C., Sutherland, W. J., Parker, C., Lobley, M., Winter, M., Morris, C., Twining, S., Ffoulkes, C., Amano, T., \& Dicks, L. V. (2016). Decision support tools for agriculture: Towards effective design and delivery. Agricultural Systems, 149, 168-174. https://doi.org/10.1016/j.agsy.2016.09.009

Roshanfekr, S., Tawil, N. M., \& Goh, N. A. (2016). Investigation of sustainable housing criteria. In MATEC Web of Conferences, 66, 00096. https://doi.org/10.1051/matecconf/20166600096

Rudzkienè, V., \& Burinskienè, M. (2007). Information models for evaluation and management of development directions (pp. 160-248). Vilnius Gediminas Technical University.

Said, R., Majid, R. Ab., Alias, A., Adnan, Y. M., \& Razali, M. N. (2016). Sustainable housing affordability in Sabah. Journal of the Malaysian Institute of Planners, 5, 65-76. https://doi.org/10.21837/pmjournal.v14.i5.193

Salehi, A., \& Izadikhah, M. (2014). A novel method to extend SAW for decision-making problems with interval data. Decision Science Letters, 3, 225-236. https://doi.org/10.5267/j.dsl.2013.11.001
Saraff, A. Z., Mohaghar, A., \& Bazargani, H. (2013). Developing TOPSIS method using statistical normalization for selecting knowledge management strategies. Journal of Industrial Engineering and Management, 6(4), 860-875. https://doi.org/10.3926/jiem.573

Shah, S. A. A., Zhou, P., Walasai, G. D., \& Mohsin, M. (2019). Energy security and environmental sustainability index of South Asian countries: A composite index approach. Ecological Indicators, 106, 105507. https://doi.org/10.1016/j.ecolind.2019.105507

Soufi, M. D., Ghobadian, B., Najafi, G., Sabzimaleki, M. R., \& Yusaf, T. (2015). TOPSIS multicriteria decision modeling approach for biolubricant selection for two stroke petrol engines. Energies, 8, 13960-13970.

https://doi.org/10.3390/en81212408

Staniūnas, M., Staniūnas, E., \& Burinskienė, M. (2010). Apllication of indices for assessing the ecological potential of urban development. Ekologija, 56(3-4), 79-86. https://doi.org/10.2478/v10055-010-0011-y

Tang, J., Zhu, H.-L., Liu, Z., Jia, F., \& Zheng, X.-X. (2019). Urban sustainability evaluation under the Modified TOPSIS based on grey relational analysis. International Journal of Environmental Research and Public Health, 16(2), 256. https://doi.org/10.3390/ijerph16020256

Totha, G., \& Szigeti, C. (2016). The historical ecological footprint: From over-populationto over-consumption. Ecological Indicators, 60, 283-291. https://doi.org/10.1016/j.ecolind.2015.06.040

Velička, R., \& Pupalienė, R. (2010). Demographic, climate change and agro-ecology links (textbook) (pp. 4-80). Department of Agriculture.

Vuuren, D., \& Smeets, E. (2000). Ecological footprints of Benin, Bhutan, Costa Rica and the Netherlands. Ecological Economics, 34(1), 115-130. https://doi.org/10.1016/S0921-8009(00)00155-5

Wackernagel, M., Monfreda, C., Schulz, N. B, Erb, K.-H., Haberl, H., \& Krausmann, F. (2004). Calculating national and global ecological footprint time series: Resolving conceptual challenges. Land Use Policy, 21(3), 271-278. https://doi.org/10.1016/j.landusepol.2003.10.006

Zhang, Y. J., Li, A., J., \& Fung, T. (2012). Using GIS and multicriteria decision analysis for conflict resolution in land use planning. Environmental Science, 13, 2264-2273. https://doi.org/10.1016/j.proenv.2012.01.215 